\title{
Kajian Konsentrasi Dan Sebaran Parameter Kualitas Air Di Perairan Pantai Genuk, Semarang
}

\author{
Sri Yulina Wulandari*, Muh. Yusuf dan Muslim \\ Jurusan Ilmu Kelautan Fakultas Perikanan dan Ilmu Kelautan Universitas Diponegoro, \\ Jl. Prof. H. Soedharto, SH, Tembalang Semarang. 50275 \\ Email : yulina.wuland@gmail.com
}

\begin{abstract}
Abstrak
Kecamatan Genuk merupakan wilayah di Semarang yang perkembangan industrinya sangat pesat, sehingga telah banyak menyumbang limbah ke perairan Genuk. Kegiatan manusia yang berpotensi besar meningkatkan konsentrasi limbah ke lingkungan perairan Genuk berasal dari kegiatan industri yang banyak terdapat di sepanjang Jalan Raya Kaligawe, kawasan industri Terboyo, dan kawasan Lingkungan Industri Kecil (LIK). Limbah yang dibawa oleh sungai akan mencapai perairan pantai, yang kemudian akan dapat didistribusikan ke segala arah oleh arus laut.

Tujuan penelitian adalah untuk mengetahui konsentrasi dan sebaran parameter kualitas air di perairan pantai Genuk, Semarang dan pengaruh kecepatan arus terhadap sebaran parameter kualitas perairan.

Penelitian ini dilaksanakan selama 5 bulan, dimulai bulan Juni sampai Oktober 2013 meliputi penyusunan proposal, persiapan penelitian, pelaksanaan penelitian, analisis laboratorium hingga penyusunan laporan akhir. Pengambilan sampel air dan sedimen di lapangan dilakukan pada tanggal 4 Mei 2013.

Metode yang digunakan dalam penelitian ini adalah metode diskriptif. Pengambilan data dilakukan dengan metode survei, dan metode sampling yang dipergunakan adalah purposive sampling.

Hasil penelitian menunjukkan bahwa parameter fisika dan kimia seperti temperatur, salinitas, $\mathrm{pH}$ dan DO secara berturut-turut berkisar $28-32{ }^{\circ} \mathrm{C}, 31-32,5 \% 0,6,7-7,9$ dan $7,1-8,3$ ppm dengan nilai rata-rata $30,95^{\circ} \mathrm{C}, 14,41 \% \mathrm{o}, 7,05$ dan 5,95 ppm. Konsentrasi nitrat, fosfat terlarut dan $\mathrm{Pb}$ dalam sedimen adalah $0,291-0,349$ ppm (tingkat kesuburan sedang), 0,175-0,215 ppm (tingkat kesuburan sangat baik), dan 15,89 $-23,02 \mathrm{ppm}$. Kecepat arus yang terjadi saat penelitian adalah 0,0222 $\mathrm{m} / \mathrm{det}-0,1985 \mathrm{~m} / \mathrm{det}$ yang kurang mampu mempengaruhi sebaran, karena sebaran parameter kimia dan fisika lebih dipengaruhi oleh jauh dekatnya dengan pantai atau daratan.
\end{abstract}

Kata kunci: Perairan Genuk, polutan, tingkat pencemaran, sebaran

\section{PENDAHULUAN}

Genuk adalah daerah pesisir Semarang yang paling pesat laju pembangunan industrinya yang diikuti dengan meningkatnya jumlah penduduk dan pemukiman. Secara nyata telah menimbulkan dampak berupa meningkatnya jumlah buangan limbah (waste) baik yang berasal dari berbagai kegiatan industri maupun intensifikasi pertanian dan perikanan (tambak ikan/udang), pengembangan permukiman, pengembangan pelabuhan, lalulintas kapal-kapal laut, dan bentuk-bentuk kagiatan manusia lainnya, yang telah mencemari air, tanah dan udara.

Perairan pantai Genuk tepatnya berada di wilayah Kelurahan Terboyo dan Kelurahan
Trimulyo, Kecamatan Genuk, Pemerintah Kota Semarang, Propinsi Jawa Tengah. Secara geografis perairan Genuk terletak pada posisi antara $06^{\circ} .53^{\prime} 00^{\prime \prime}$ LS - 06 $.57^{\prime} 00^{\prime \prime}$ LS dan $110^{\circ} .24^{\prime} .00^{\prime \prime}$ BT - $110^{\circ} .26^{\prime} .00^{\prime \prime}$ BT (Gambar 1).

Jenis limbah yang sering menurunkan kualitas perairan adalah logam berat, nutrien dan bahan organik yang mempengaruhi parameter kualitas perairan yang lain seperti $\mathrm{pH}$, oksigen terlarut, kekeruhan yang akhirnya mengganggu kehidupan organisme. Penyebab utama logam berat menjadi limbah berbahaya karena logam berat tidak dapat dihancurkan (non degradable) oleh organisme hidup di lingkungan dan terakumulasi ke lingkungan, terutama mengendap 
di dasar perairan membentuk senyawa komplek bersama bahan organik dan anorganik secara adsorbs dan kombinasi (Djuangsih, 1982 dalam Rochyatun dan Rozak, 2007). Menurut Sanusi (2006) daftar urutan toksisitas logam paling tinggi ke paling rendah terhadap manusia adalah $\mathrm{Hg}>$ $\mathrm{Cd}>\mathrm{Ag}>\mathrm{Ni}>\mathrm{Pb}>\mathrm{As}>\mathrm{Cr}>\mathrm{Sn}>\mathrm{Zn}$. Sedangkan yang banyak dihasilkan bersama dengan bahan bakar yang dipakai adalah $\mathrm{Pb}$ yang masuk dalam logam berbahaya (toxic).

Menurut Spencer et al., (2012) dan Muslim (2013) dikatakan bahwa tingkat aktivitas manusia seperti tingkat budidaya ikan atau udang yang dipakai sebanding dengan jumlah atau produksi limbah organik yang dihasilkan, padahal sebagian besar kegiatan budidaya di pantai utara Jawa belum dilengkapi dengan treatmen limbah sebelum dibuang ke perairan umum atau laut. Selanjutnya Yusuf (2005) menyatakan bahwa masalah pencemaran air di sepanjang pantai Utara Pulau Jawa sudah sangat memprihatinkan, hal tersebut disebabkan karena pengembangan industri dipusatkan di wilayah tersebut terutama dalam bentuk kawasan-kawasan industri.

Berdasarkan atas pemberitaan yang pernah beberapa kali muncul di mass media (Suara Merdeka dan Kompas pada tahun 2000) serta berdasarkan atas hasil pra survei (secara visual) ke lapangan pada tahun 2009, perairan pantai Genuk diduga telah tercemar karena menerima dan menampung buangan limbah yang berasal dari sejumlah industri yang terdapat di kawasan industri Terboyo, kawasan Lingkungan Industri Kecil (LIK), dan sepanjang jalan raya Kaligawe. Berdasarkan data yang tercatat di Kantor Wilayah Departemen Perindustrian Propinsi Jawa Tengah (1999) disebutkan bahwa sejumlah industri yang beroperasi di kawasan industri Terboyo dan sepanjang jalan raya Kaligawe yang merupakan hulu sungai Babon dan sungai Banjir Kanal Timur terdiri dari sejumlah industri yang menghasilkan produk-produk kertas, kemasan karton, percetakan, garmen pakaian, tekstil, penyamakan kulit, galvanis, baterai, keramik, cold storage ikan dan udang, makanan dan bumbu masak (penyedap masakan). Jenis-jenis industri ini sangat berpotensi menghasilkan limbah-limbah organik dan anorganik yang bersifat racun yang sangat membahayakan bagi kehidupan organisme perairan.

Kegiatan pertanian termasuk perikanan tambak berpotensi menghasilkan limbah nitrogen dan fosfor yang berasal dari kegiatan pemupukan dan pemberian pakan udang yang mengandung unsur nitrogen dan fosfor (pupuk ZA, TSP) akan menyebabkan eutrofikasi perairan dan tumbuhnya gulma air termasuk fitoplankton, sehingga terjadi proses pembusukan dan pengendapan yang dapat menimbulkan bau menyengat $\left(\mathrm{H}_{2} \mathrm{~S} ; \mathrm{NH}_{3}\right)$ dan berkurangnya kadar oksigen terlarut dalam air (Muslim, 2009). Eutrofikasi dapat menyebabkan organisme fitoplankton sangat melimpah yang diikuti oleh proses dekomposisi bahan organik oleh mikroorganisme yang dapat menghasilkan senyawa beracun dari $\mathrm{N}-\mathrm{NH}_{3} ; \mathrm{H}-\mathrm{H}_{2} \mathrm{~S}$ dan berkurangnya oksigen terlarut di dalam air. Kondisi demikian pada akhirnya dapat menurunkan keanekaragaman organisme makrobenthos yang hidupnya relatif menetap di dasar perairan.

Kegiatan industri tidak hanya membuang limbah kimia, tapi juga mengakibatkan meningkatnya kekeruhan perairan dari partikel. Padatan yang tersuspensi ini dapat berasal dari sisa pakan yang tak termakan dan feces yang tidak terendapkan menunjukkan dampak negatip yang tidak langsung terhadap kehidupan hewan atau ikan (El-Shafey, 1998). Menurut Stickney (1979) dan Wickens (1980) walaupun padatan tersuspensi tersebut berukuran kecil tetap dapat menyebabkan iritasi insang yang akan berakibat pada menurunnya sistem kekebalan dan akhirnya mudah kena penyakit.

Limbah padat ini akan mengkonsumsi oksigen dan memproduksi carbon dioxide dan ammonia saat terjadinya dekomposisi oleh bakteri (Muslim et al., 2004 ${ }^{\mathrm{b}}$ ). Kandungan oksigen terlarut yang berkurang akan mengganggu proses metabolisme ikan dan selanjutnya akan berpengaruh pada pertumbuhan dan konversi pakan (Huisman 1976 dalam Harris 1982). Padahal oksigen terlarut kurang dari $1 \mathrm{ppm}$ menyebabkan kematian bagi ikan jika dibiarkan 
lama atau ikan tidak dapat bertahan hidup, dan akan menyebabkan pertumbuhan dan reproduksinya lambat jika kadar oksigennya antara 1-5 ppm. Untuk itu untuk menjaga kenormalan pertumbuhan dan dapat bereproduksi, maka diperlukan kadar oksigen terlarut lebih dari 5 ppm (Swingle,1969). Turunnya oksigen juga akan menyebabkan turunnya efficiensi bionitrifying, tingginya kekeruhan dan munculnya pathogens (Skjolstrup et al., 1998; Singh et al., 1999; Cripps dan Berheim, 2000; Losordo dan Hobbs, 2000; Melano dan Beecher, 2000). Dekomposisi yang terjadi di dasar perairan dapat menyebabkan kondisi anoxic di dasar. Hal ini sangat membahayakan kehidupan organisme dasar seperti udang.

Proses dekomposisi biasanya juga mengakibatkan turunnya $\mathrm{pH}$. Ikan tidak dapat hidup baik pada $\mathrm{pH}$ yang rendah atau asam (Leivestad, 1982 dalam Boyd, 1990). Menurut Boyd (1990), jaringan insang menjadi organ sasaran utama terkena stress asam. Titik kematian ikan biasanya terjaadi pada $\mathrm{pH} 4$ (asam) dan $\mathrm{pH}$ 11 (basa). Menurut Swingle (1969), derajat keasaman yang baik untuk menjamin kehidupan organisme laut seperti ikan adalah berkisar antara 6,5 - 8,5. Derajat keasaman air yang berkisar antara 4,0 sampai 6,5 menyebabkan pertumbuhan ikan lambat.

Jadi perairan yang baik untuk kehidupan organisme laut adalah yang tidak banyak mengandung padatan tersuspensi, bahan organik baik yang terendap maupun yang tersuspensi (Chen et al., 1994; Blancheton, 2000; Timmons et al., 2001, Nava et al., 2004).

Untuk mengetahui seberapa jauh konsentrasi dan sebaran parameter kualitas air di perairan pantai Genuk dan bagaimana sebarannya, maka dirasa penting untuk melakukan penelitian tentang "Kajian konsentrasi dan sebaran kualitas air di Perairan Pantai Genuk Semarang".

Tujuan utama dari penelitian ini adalah untuk mengetahui konsentrasi dan sebaran parameter kualitas air di perairan pantai Genuk, Semarang dan pengaruh kecepatan arus terhadap sebaran parameter kualitas perairan.

\section{MATERI DAN METODE}

Materi penelitian yang dipakai dalam penelitian ini adalah sampel air dan sampel sedimen dasar perairan yang diambil dari sejumlah stasiun penelitian yang telah ditentukan sebelumnya sebanyak 11 stasiun (Gambar 1). Sampel air diambil untuk dianalisa konsentrasi sejumlah parameter kualitas air, meliputi: Muatan Padatan Tersuspensi, Bahan organik, nitrat, fosfat dan bahan organik, yang diambil secara langsung dengan menggunakan botol-botol sampel dari bahan polyethilen, dengan pertimbangan kedalaman air relatif dangkal kurang dari 5 meter. Sedangkan parameter lain seperti temperatur, $\mathrm{pH}$, salinitas, oksigen terlarut diukur secara langsung (insitu). Sedimen diambil dengan grab untuk mengetahui jenis sedimen, total bahan organik sedimen dan Kandungan $\mathrm{Pb}$ disedimen.

Metode pengambilan sampel air dilakukan pada lapisan permukaan, mengingat kedalaman air relatif dangkal. Sampel air diambil dengan menggunakan botol sampel polyethylin (PE) volume $500 \mathrm{~mL}$ yang sebelumnya telah direndam dengan asam nitrat $(0,5 \%)$ selama minimal semalam (Reichelt dan Jones, 1994). Sebelum air diambil pada masing-masing stasiun, botol sampel terlebih dulu dibilas dengan air sampel minimal 2 kali. Selanjutnya botol sampel yang telah berisi sampel air laut disimpan dalam cool box yang berisikan balok/batu es dan langsung dibawa ke laboratorium untuk dianalisa kandungan fosfat dan nitrat dengan menggunakan Spektrofotometer (Parson et al., 994) dan kandungan bahan organik terlarut dianalisa dengan metode permanganometri.

Sampel sedimen diambil pada saat perairan mulai surut dengan menggunakan Ekman Grab ukuran $15 \times 15 \mathrm{~cm}$ yang terbuat dari stainless steel pada lapisan permukaan sedimen. Contoh sedimen kemudian dimasukkan ke dalam tabung kecil yang terbuat dari polietilen yang terlebih dahulu dibersihkan dengan air PAM, kemudian dilakukan perendaman dalam $\mathrm{HNO}_{3}$ 1:1 selama semalam dan dibilas tiga kali dengan air suling bebas ion. Wadah polietilen yang telah terisi contoh sedimen kemudian dibungkus dengan 


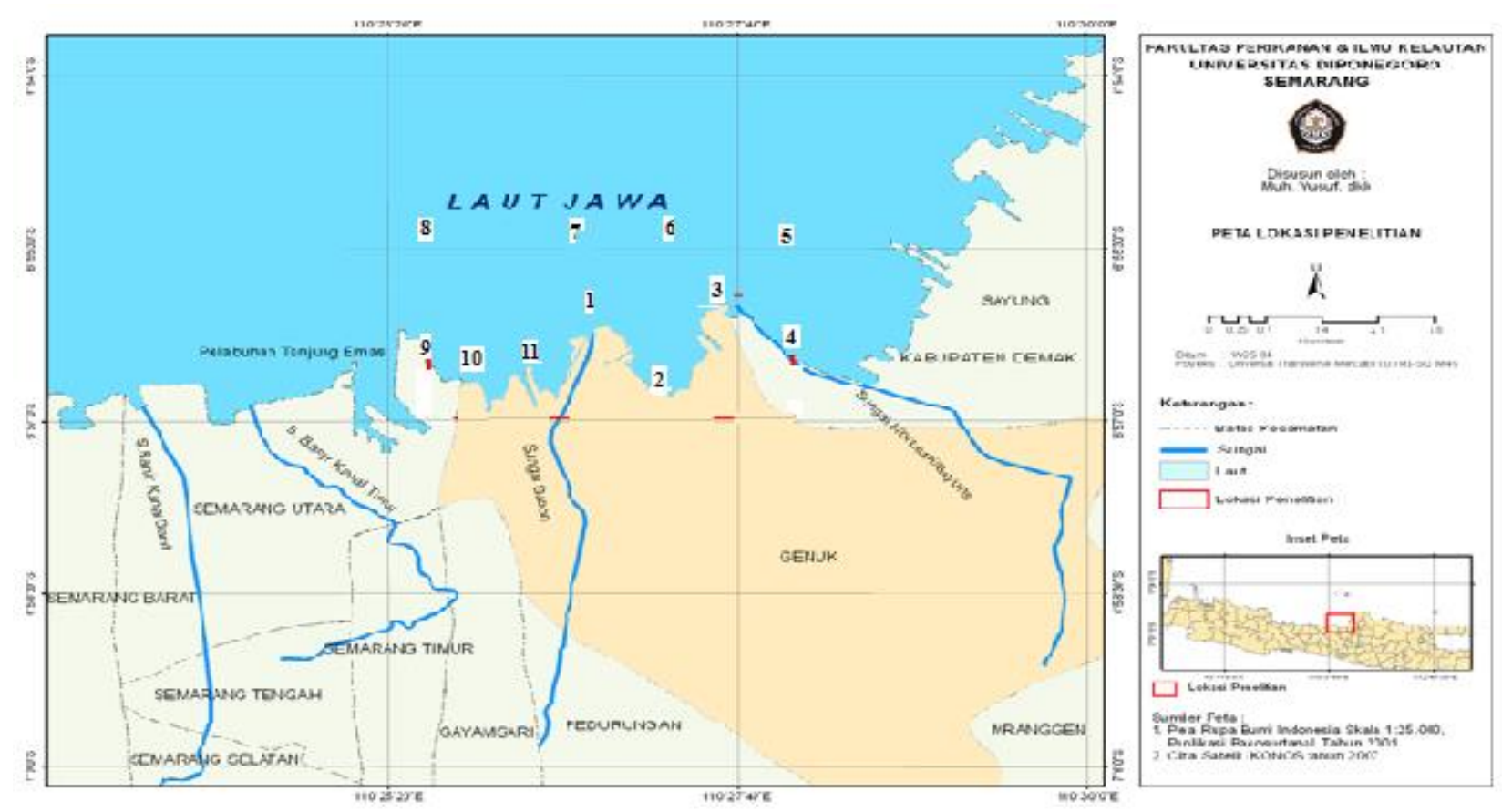

Gambar 1. Peta Lokasi Penelitian

kantong plastik strep dan disimpan ke dalam kotak es, selanjutnya langsung dibawa ke Laboratorium Kimia dan Laboratorium Geologi Laut FPIK, UNDIP untuk dianalisis kandungan karbon organik total.

Sedimen tersebut sebelum dipanaskan pada temperatur $550{ }^{\circ} \mathrm{C}$ telah direndam dalam $1 \mathrm{~N} \mathrm{HCl}$ untuk melepaskan mineral karbonatnya (Zhao et al.,2007). Perhitungan kandungan TOC dengan menggunakan persamaan Allen et al. (1976), yaitu sebagai berikut :

$$
\mathrm{Li}=\frac{\text { Wo }-\mathrm{Wt}}{\text { Wo }} \times 100 \%
$$

Di mana :

$\mathrm{Li}=$ loss on ignation $(\%)$

Wo = berat awal (gram)

$\mathrm{Wt}=$ berat akhir (gram)

Kelas tekstur sedimen ditentukan berdasarkan persentase fraksi pasir (sand), debu (silt), dan liat (clay). Kemudian dikelompokkan menurut diagram segitiga dari USDA (Brower dan Zar, 1977).

Analisis kadar Timbal dalam sedimen dasar menggunakan metode destruksi asam dengan spektrofotometer serapan atom (SSA). Metode SSA berprinsip pada absorsi cahaya oleh atom, atom dapat menyerap cahaya tersebut pada panjang gelombang tertentu. Cahaya pada panjang gelombang ini mempunyai cukup energi untuk mengubah energi elektronik suatu atom (Nisma, 2008). Pengukuran kadar Timbal menggunakan panjang gelombang sebesar 217,0 nm (SNI 066992.3: 2004). Pengukuran kadar Timbal dalam sedimen menggunakan metode Standar Nasional Indonesia (SNI) secara destruksi asam.

\section{Pemodelan Pola Arus 2 Dimensi}

Data kecepatan dan arah arus yang diperoleh di lapangan dibuat model dengan bantuan program sebagai berikut:

\section{1) SMS (Surface Water Modelling System)}

SMS (Surface-Water Modelling System) adalah suatu program untuk memecahkan model matematika yang dibangun berdasarkan konsep gerak air dan gerak sedimen secara matematis dipecahkan dengan menggunakan metode elemen hingga melalui pendekatan 2D horizontal. Terdiri dari beberapa modul, yaitu TABS-MD (GFGEN, 
RMA2, RMA4, RMA10, SED2D-WES), ADCIRC, CGWAVE, STWAVE, dan HIVEL2D.

2) ADCIRC (Advanced Circulation Multi Dimensional Hydrodynamic Model)

Untuk penentuan pola karateristik arus laut dilakukan pendekatan model ADCIRC (Advanced Circulation Multi Dimensional Hydrodynamic Model) mendasarkan pembuatan model arus laut dengan basis data pasang surut dan titik kedalam yang dibuat menjadi suatu kontur batimetri. Persamaan dasar hidrodinamika dalam menentukan arus pasut terdiri persamaan kontinuitas dan persamaan momentum.

Persamaan Momentum (gerak)

$$
\frac{\partial \zeta}{\partial t}+\mathrm{H} \frac{\partial u}{\partial x}=0
$$

Persamaan Kontinuitas

$$
\frac{\partial u}{\partial t}+\mathrm{g} \frac{\partial \zeta}{\partial x}=0
$$

Persamaan ini mengasumsikan shear stress horizontal dianggap kecil sehingga diabaikan, suku konvektif pada persamaan momentum diabaikan, karena dalam arus pasut nilainya sangat kecil. Dalam persamaan momentum, pergerakan fluida ditimbulkan oleh suku gradient tekanan dan suku gesekan dasar. Dalam persamaan kontinuitas fluida dianggap ideal dengan densitas uniform dan inkompresibel (Luettich dan Westerink, 2000).

\section{HASIL DAN PEMBAHASAN \\ Kondisi Parameter Kualitas Air}

Parameter kualitas yang telah diukur secara insitu meliputi temperatur, salinitas, $\mathrm{pH}$, oksigen terlarut (DO), kecerahan dan material padatan tersuspensi (MPT) dengan nilai berfluktuasi pada kisaran nilai masing-masing $30-31,9{ }^{\circ} \mathrm{C} ; 3,5-29$ $\%_{0} ; 6,5-7,8 ; 2,91-9,22 \mathrm{ppm} ; 12-40 \mathrm{~cm}$; dan 9,5$28,1 \mathrm{mg} / \mathrm{L}$ (ppm). Hasil pengukuran parameter tersebut yang diperoleh langsung diukur di lapangan secara detailnya tersaji dalam Tabel 1 .

\section{Kandungan Bahan Organik di air dan Sedimen, Jenis Sedimen}

Bahan organik yang terkandung di air dan di sedimen menunjukkan nilai yang sangat berbeda. Sebaran kandungan bahan organik sangat dipengaruhi oleh letak dan jenis sedimennya. Konsentrasi dari bahan organik baik yang terdapat di air maupun sedimen nilainya masing dari yang paling rendah ke yang paling tinggi adalah 14,1 -20,9 ppm (di air) dan 8,1 $12,8 \%$ (dalam sedimen). Jenis sedimennya hampir sama yaitu lanau dan pasir lanauan. Data detail pada tiap stasiun disajikan pada Tabel 2.

Tabel 1. Nilai temperatur $\left({ }^{\circ} \mathrm{C}\right)$, salinitas $(\%)$, DO $(\mathrm{ppm})$, kecerahan $(\mathrm{cm})$ dan material padatan tersuspensi (MPT) (ppm)

\begin{tabular}{cccccccc}
\hline No & Stasiun & Temperatur & Salinitas & $\mathrm{pH}$ & DO & Kecerahan & MPT \\
\hline 1 & 1 & 30 & 3,5 & 6,5 & 2,91 & 12 & 28,1 \\
2 & 2 & 30,2 & 9,5 & 6,7 & 4,15 & 19 & 25,0 \\
3 & 3 & 30,2 & 4,5 & 6,7 & 3,95 & 15 & 27,5 \\
4 & 4 & 30,5 & 4,5 & 6,8 & 4,81 & 17 & 20,1 \\
5 & 5 & 30,9 & 27,5 & 7,5 & 7,95 & 35 & 11,3 \\
6 & 6 & 30,9 & 29,0 & 7,8 & 8,20 & 37 & 10,9 \\
7 & 7 & 31,8 & 28,0 & 7,5 & 7,95 & 40 & 10,2 \\
8 & 8 & 31,9 & 28,5 & 7,7 & 9,22 & 39 & 9,5 \\
9 & 9 & 31,5 & 11,5 & 6,9 & 6,21 & 25 & 17,5 \\
10 & 10 & 31,6 & 6,5 & 6,8 & 5,25 & 21 & 16,3 \\
11 & 11 & 30,9 & 5,5 & 6,6 & 4,85 & 22 & 18,5 \\
\multicolumn{2}{c}{ Rata-rata } & 30,95 & 14,41 & 7,05 & 5,95 & 25,64 & 17,72 \\
\hline
\end{tabular}




\section{Konsentrasi Nutrien Terlarut dan Logam Berat Pb di Sedimen}

Nutrient yang diukur dalam penelitian ini hanya unsur $\mathrm{N}$ (Nitrat) terlarut dan Inorganik fosfat terlarut, karena kedua nutrien tersebut yang sering menjadi unsur pembatas suatu pertumbuhan fitoplankton di perairan. Sedangkan logam berat yang diukur hanya $\mathrm{Pb}$ (timbal) yang terkandung di sedimen, karena disamping unsur $\mathrm{Pb}$ termasuk unsur yang toxic (beracun) juga paling banyak dihasilkan oleh kegiatan industri. Konsentrasi nitrat yang terdeteksi dari 0,291 $0,349 \mathrm{ppm}$, inorganik fosfat terlarut terdeteksi pada 0,175-0,215 ppm, sedangkan parameter $\mathrm{Pb}$ dalam sedimen kisaran konsentrasinya 15,89 23,02 ppm. Secara detailnya ke tiga parameter tersebut tersaji dalam Tabel 3.

\section{Kondisi Arus}

Pengukuran arus dilakukan dari perairan sebelah timur wilayah kecamat Genuk, Semarang, tepatnya di Perairan Sayung kota Demak. Hasil yang diperoleh dimodelkan sampai ke perairan Genuk Semarang. Kecepatan dan arah arus yang dilakukan pada saat penelitian menunjukkan arah arus dominan di permukaan mengalir dari Tenggara ke Barat Laut. Kecepatan arus maksimal di permukaan mencapai $0,1985 \mathrm{~m} / \mathrm{det}$, kecepatan arus minimal adalah $0,0222 \mathrm{~m} / \mathrm{det}$. Arah arus yang terjadi tersaji dalam Gambar 2.

\section{Pembahasan}

\section{Kimia Fisika Perairan Genuk}

Parameter temperatur, salinitas, $\mathrm{pH}$ dan $\mathrm{DO}$ (Tabel 2) pada setiap stasiun maupun nilai rataratanya secara berturut-turut terukur $30,95^{\circ} \mathrm{C}$, 14,41\%, 7,05 dan 5,95 ppm masih layak untuk kehidupan organisme khususnya organisme tropis, bahkan $\mathrm{pH}$ 7,05 merupakan $\mathrm{pH}$ air yang baik untuk kehidupan suatu organisme air, karena kisaran $\mathrm{pH}$ yang baik adalah sekitar 7 (Hutchinson et al., 2004). Demikian juga untuk oksigen terlarutnya dengan nilai paling rendah $2,91 \mathrm{ppm}$ dan rata-ratanya $5,95 \mathrm{ppm}$, menunjukkan secara keseluruhan daerah perairan Genuk masih baik untuk kehidupan organisme, karena konsentrasi yang masih ditolerir oleh kehidupan udang adalah
DO dengan konsentrasi > 3 ppm (Sutomo dan Mu'minah, 2004). Adapun temperatur yang baik untuk daerah tropis adalah $25-31{ }^{\circ} \mathrm{C}$.

\section{Tingkat Konsentrasi Nutrien, Bahan Organik dan $\mathrm{Pb}$}

Konsentrasi nitrat yang terdeteksi di perairan Genuk 0,291 - 0,349 ppm merupakan konsentrasi yang rendah ditinjau dari kesuburannya, karena menurut Malaha (2004) bahwa konsentrasi nitrat 1,0-5,0 ppm merukanan tingkat kesuburan sedang. Sedangkan konsentrasi fosfat yang terdeteksi $0,175-0,215 \mathrm{ppm}$ (Tabel 4) merupakan perairan dalam katagori sangat baik, karena kisaran sangat baik adalah bila konsentrasi fosfatnya $0,110-0,210 \mathrm{ppm}$.

Bahan organik merupakan indikator dari pada tingkat kebutuhan oksigen secara kimia atau COD (APHA, 1992). Tingginya bahan organik (Tabel 3), khususnya di sedimen menunjukkan bahwa sedimen di perairan Genuk sudah banyak mengakumulasi limbah organik (Muslim et al, $2004^{\text {b }}$ ). Demikian juga kandungan $\mathrm{Pb}$ yang terkandung di sedimen (Tabel 3) mengindikasikan bahwa dasar sedimen yang banyak didominasi oleh jenis sedimen lanau sangat kuat untuk mengikat logam $\mathrm{Pb}$. Hal ini sesuai dengan pendapat Reichelt dan Jones (1994) yang mengatakan bahwa sedimen merupakn sink dari semua elemen yang ada diperiaran.

\section{Sebaran Elemen}

Dilihat dari Tabel 3 dan 4 terlihat bahwa senyawa nitrat, fosfat, bahan organik dan $\mathrm{Pb}$ terlihat konsentrasinya meningkat saat berada pada stasiun yang dekat dengan daratan dan yang paling tinggi selalu di stasiun 1 , walaupun ada gerakan arus di perairan Genuk. Tingginya konsentrasi suatu senyawa di muara sungai, menunjukkan bahwa sumber senyawa tersebut adalah dari aktivitas daratan atau yang dekat dengan sumbernya (Saad dan Younes, 2006). Demikian juga Reichet dan Jones (1994) juga mendukung bahwa tingginya konsentrasi senyawa di periran muara karena di daerah tersebut terjadi proses pengadukan. Rendahnya konsentrasi senyawa yang jauh dari pantai , disamping karena jauh dengan sumbernya, juga karena sudah terjadi pengenceran (Millero dan Sohn, 1992). 
Tabel 2. Konsentrasi Bahan Organik Total Air Laut (ppm) dan Konsentrasi bahan organik di Sediment (\%) dan Jenis sedimen

\begin{tabular}{ccccl}
\hline No & Stasiun & Air laut & Sedimen & Jenis Sedimen \\
\hline 1 & 1 & 20,9 & 12,8 & Lanau \\
2 & 2 & 17,3 & 11,9 & Lanau \\
3 & 3 & 16,8 & 11,2 & Lanau \\
4 & 4 & 18,1 & 12,1 & Lanau \\
5 & 5 & 16,4 & 11,1 & Pasir lanauan \\
6 & 6 & 14,7 & 8,4 & Pasir lanauan \\
7 & 7 & 14,1 & 8,1 & Pasir lanauan \\
8 & 8 & 14,1 & 8,2 & Pasir lanauan \\
9 & 9 & 17,8 & 10,9 & Lanau \\
10 & 10 & 17,3 & 11,1 & Lanau \\
11 & 11 & 18,2 & 12,1 & Lanau \\
\hline
\end{tabular}

Tabel 3. Konsentrasi (ppm) Nitrat terlarut, Fosfat Inorganik Terlarut dan Logam Pb di Sedimen.

\begin{tabular}{ccccc}
\hline No & Stasiun & Nitrat & Fosfat & $\mathrm{Pb}$ \\
\hline 1 & 1 & 0,349 & 0,215 & 23,02 \\
2 & 2 & 0,332 & 0,211 & 22,97 \\
3 & 3 & 0,341 & 0,212 & 22,85 \\
4 & 4 & 0,339 & 0,210 & 22,96 \\
5 & 5 & 0,291 & 0,191 & 15,89 \\
6 & 6 & 0,302 & 0,189 & 15,92 \\
7 & 7 & 0,314 & 0,198 & 16,23 \\
8 & 8 & 0,293 & 0,175 & 16,11 \\
9 & 9 & 0,341 & 0,209 & 21,24 \\
10 & 10 & 0,342 & 0,211 & 21,75 \\
11 & 11 & 0,337 & 0,207 & 22,01 \\
\hline
\end{tabular}
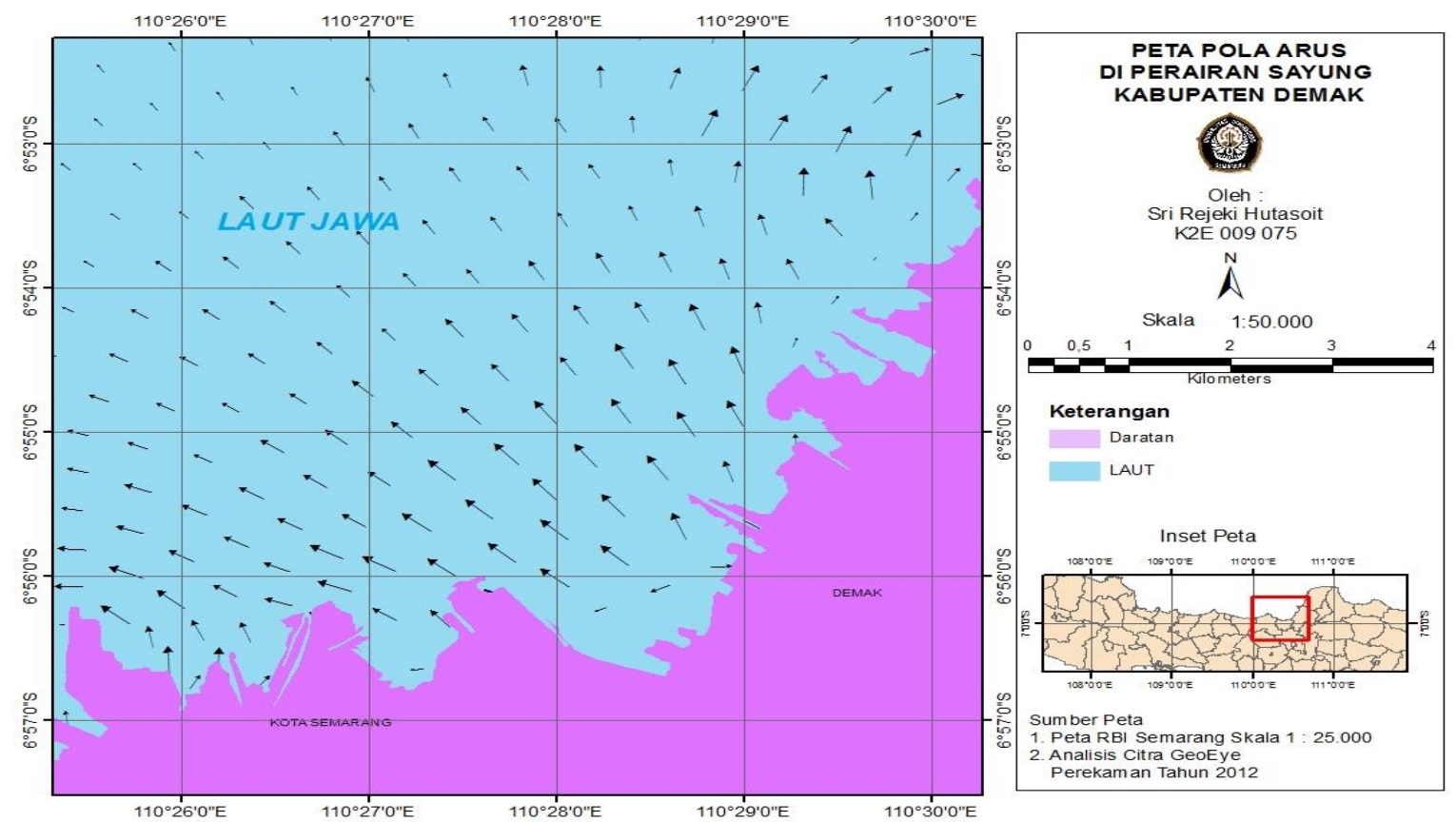

Gambar 2. Peta Arus Perairan Sayung 
Berdasarkan kejadian tersebut di atas dapat dikatakan bahwa arus yang terjadi saat pengambilan sampel tidak mampu mempengaruhi pada sebaran senyawa, hal ini dimungkinkan karena arus yang terjadi tidak terlalu kuat, sehingga disamping tidak mampu membawa juga tidak mempengaruhi pengadukan. Muslim dan Jones (2003) mengatakan bahwa lepasnya suatu senyawa di suatu perairan dapat dipengaruhi oleh proses pengadukan.

\section{SIMPULAN}

Berdasarkan hasil yang diperoleh dalam penelitian ini maka dapat disimpulkan bahwa parameter temperatur, salinitas, $\mathrm{pH}$ dan oksigen terlarut masih dalam katagori normal untuk kehidupan organisme laut, karena konsentrasi rata-ratanya secara berturut-turut adalah $95^{\circ} \mathrm{C}$, $14,41 \%$, 7,05 dan 5,95 ppm. Adapun konsentrasi nitrat masuk dalam katagori rendah $(0,291-0,349$ ppm) dan fosfatnya dalam katogori sangat baik $(0,175-0,215$ ppm). Akan tetapi kondisi sedimennya sudah relatip tinggi konsentrasi bahan organiknya $(8,1-12,8 \%)$ dan Pbnya $(15,89$ 23,02 ppm).

Sebaran parameter kimianya (nutrien, bahan organik dan $\mathrm{Pb}$ ) menunjukkan bahwa makin jauh dari daratan konsentrasinya makin mengecil, sehingga sebarannya tidak banyak dipengaruhi oleh arus yang terjadi saat pengambilan sampel.

\section{UCAPAN TERIMA KASIH}

Terima kasih kepada sponsor penelitian ini yaitu dana PNBP Universitas Diponegoro TA 2013 dengan Nomor perjanjian kontrak : 3577/UN7.3.10/PL/2013 tanggal 09 September 2013. Selanjutnya penghargaan dan ucapan terima kasih disampaikan kepada pengelola laboratorium pesisir dan oseanografi tropis Universitas Diponegoro yang telah memberi fasilitasnya. Dan tak lupa pada Sdri Sri Rejeki dan Rizki Amalia yang telah banyak membantu dalam analisa dan pengolahan data sehingga penelitan ini dapat berjalan lancar serta reviewer yang telah memberi masukan dan arahan dalam penyempurnaan penulisan.

\section{DAFTAR PUSTAKA}

APHA. 1992. Standard Methods for the Examination of Water and Wastewater.

Aquacop, 1983. Macrobracium rosenbergii de Man culture in Polynesia: Progres indeveloping a mass intensive larval rearing technique in clear water. Centre Oceanologique der Pacifique CNEXO COP. B.P. 7004 Taravao, Tahiti

Astuty. R.D. 2011. Kandungan Logam Berat Cd dan $\mathrm{Cu}$ Berdasarkan Ukuran Partikel Sedimen di Perairan Teluk Jakarta. Skripsi Sarjana Fakultas Perikanan dan Ilmu Kelautan Institut Pertanian Bogor, Bogor.

Blancheton, J.P. 2000. Developments in Recirculation Systems for Mediterranean Fish Species. Aquacultural Eng. 22, 17-31.

Boyd, C.E. 1990. Water Quality In Pond for Aquaculture. Departement of Fisheries and Allied Aquacultures. Auburn University, Alabama.

Brinker, A., Schroder, H.G and Rosch, R. 2005. A High-Resolution Technique to Size Suspended Solids in Flow-Through Fish Farms. Aquacultural Eng. 32, 325-341.

Brower, J.E. and Zar, J.H. 1977. Field and Laboratory Methods for General Ecology. W.M.C. Brown Comp. Publising Co. Inc. New York.

CERC. 1984. Shore Protection Manual. Waterways Experiment Station - US Army Corps of Engineers. Mississippi.

CERC. 2003. Coastal Engineering Manual. Coastal and Hydraulics Laboratory -

Waterways Experiment Station. US Army Corps of Engineers. Mississippi.

Chen, S., Stechey, D and Melone, F. 1994. Suspended Solids Control in Recirculating Aquaculture Systems. In: Timmons, M.B., Losordo, T.M. (Eds.), Aquaculture Water Reuse Systems: Engineering Design and Management. Development in Aquaculture and Fisheries Sciences, Vol. 27. Elsevier, Amsterdam, pp. 61-100.

Cripps, S.J. and Bergheim, A. 2000. Solids Management and Removal for Intensive land-based Aquaculture Production Systems. Aquacultural Eng. 22, 33-56. 
Darmono. 1995. Logam dalam Sistem Biologi Makhluk Hidup. Universitas Indonesia. Jakarta.

El-Shafey, A.A.M. 1998. Effect of Ammonia on Respiratory Functions of Blood of Tilapia zilli. Comparative Biochemistry and Physiology Part A, 121, 305-313.

Farhudin. 1999. Analisis Arus Laut Perairan Teluk Jakarta. [Tugas Akhir]. Jurusan Geofisika dan Meteorologi FMIPA. Institut Teknologi Bandung. Bandung.

Garno, Y.S. 2004. Pengembangan Budidaya Udang dan Potensi Pencemarannya pada Perairan Pesisir. Jurnal Teknologi Lingkungan, 5(3), 187-192.

Hadi, S. 2002. Arus Laut. Institut Teknologi Bandung (ITB).

Hamidah, R. 1981. Pengaruh Logam Berat Terhadap Lingkungan. Lembaga Oseanologi Nasional (LON) LIPI Jakarta.

Henderson, J.P. and Bromage, N.R. 1988. Optimizing the Removal of Suspended Solids from Aquaculture Effluents in Settlement Lakes. Aquacultura Eng. 7, 167-188.

Hutchinson, W., Jeffrey, M., O'Sullivan, D., Casement, D and Clarke, S. 2004. Recirculating Aquaculture Systems: Minimum Standards for Design, Construction and Management. South Australian Research and Development Institute.

Kantor Wilayah Departemen Perindustrian Propinsi Dati I Jawa Tengah. 1999. Daftar Nama Perusahaan Industri di Jawa Tengah. Kanwil Dep. Perindustrian Propinsi Jawa Tengah.

Lakhan, V.C. and Trenhaile, A.S. 1989. Applications in Coastal Modelling. Elsevier Science Publishers, Netherlands, 387pp.

Latief, H. 2002. Diktat Kuliah Oseanografi dan Hidrolika Pantai. Program Studi Oseanografi ITB : Bandung.

Losordo, T.M. and Hobbs, A.O. 2000. Using Computer Spreadsheets for Water Flow and Biofilter Sizing in Recirculating Aquaculture Production Systems. Aquacultural Eng. 23, 95-102
Luettich, R. A. and Westerink, J. J. 2000. A Parallel Advanced Circulation Model for Oceanic, Coastal and Estuarine Waters. University of North Caroline and University of Notre Dame.

Millero, F.S and Sohn, M.L. 1992. Chemical Oceanography, CRC Press. London.

Manulong, S. M. 2012. Kajian Kualitas Perairan di Sekitar Perairan Pelabuhan Tanjung Emas Ditinjau Kosentrasi Logam Berat Pb Pada Saat Pasang dan Surut. Skripsi Sarjana Fakultas Perikanan dan Ilmu Kelautan Universitas Diponegoro, Semarang.

Melone, R.F. and Beecher, I.E. 2000. Use of Floating Bead Filters to Recondition Recirculating Waters in Warm Water Aquaculture Production Systems. Aquacultural Eng. 22, 57-73

Muslim and Jones, G.B. 2003. Seasonal Variation of Dissolved Nutrients, Chlorophyl a and Suspended Sediments at Nerlly Bay, Magnetic Island. Estuarine, Coastal and Shelf Science, 57 (3), 445-455.

Muslim., Kim, I.B., Lee, J.H and Jo, J.Y. 2004 ${ }^{\mathrm{a}}$. Effects of Feeding Regimes on an Ammonia Excretion and Feces Production of Fingerling Rainbow Trout Oncorhynchus mykiss. $7^{\text {th }}$ Asian Fisheries Forum, Penang, Malaysia.

Muslim., Kim, I.B and Jo. J.Y. 2004 ${ }^{\text {b. Suspended }}$ Solid Removal Efficiency of IBK System Biofilter in a Semi-Recirculation Rainbow Trout Farm. Korean Aquaculture Society, Ansan, Korea.

Muslim. 2009. Tingkat Reduksi dan Oksidasi di Laut. Universitas Diponegoro Press. $62 \mathrm{hlm}$ (ISBN: 978-979-704-922-5)

Muslim. 2013. Pengurangan Racun Amonia, Bahan Organik dan Padatan Tersuspensi di Media Budidaya Udang Galah dengan Biofilter dengan Bahan Genteng Plastik Bergelombang. Bumi Lestari, 13 (1), 79-90

Nava, M.A.F., Blancheton, J.P., Deviller, G., Charrier, A and Gall, J.Y.L. 2004 Effect of Fish Size and Hydraulic Regime on Particulate Organic Matter Dynamics in a Recirculating Aquaculture System: Elemental Carbon and Nitrogen Approach. Aquaculture, 239, 179-198. 
Nontji, A. 1987. Laut Nusantara. Penerbit Djambatan. Jakarta.

Palar H. 2008. Pencemaran dan Toksikologi Logam Berat. Rineka Cipta, Jakarta, 152 hlm.

Parsons, T.R., Maita, Y and Lailli,C.M.1984. A Manual of Chemical and Biological Methods for Seawater Analysis.Pergamon Press. 173 pp.

Pickard, G. L. and Pond. S. 1983. Introduction to Physical Oceanography. The Flinders University of Australia.

Poerbandono dan Djunarsjah. 2005. Survei Hidrografi. Refika Aditama. Bandung

Reichelt, A.J and Jones, G.B. 1994. Trace Metals as Tracers of Dredging Activity in Cleveland Bay - Field and Laboratory Studies. Australian Journal of Marine and Freshwater, 45, 1-21.

Rochyatun. E dan Rozak. A. 2007. Pemantauan Kadar Logam Berat dalam Sedimen di Perairan Teluk Jakarta. Kelompok Penelitian Pencemaran Laut, Bidang Dinamika Laut, Pusat Penelitian Oseanografi, Lembaga Ilmu Pengetahuan Indonesia. Jakarta, 11(1), 28-36. Rochyatun, E., Edward dan Rozak. A. 2003. Kandungan Logam Berat $\mathrm{Pb}, \mathrm{Cd}, \mathrm{Cu}, \mathrm{Zn}, \mathrm{Ni}$, $\mathrm{Cr}$, Mn dan Fe dalam Air Laut dan Sedimen di Perairan Kalimantan Timur. ISSN: 01259830.

Saad, M.A.H and Younes, W.A.N. 2006. Level of Silicate, the Major Nutrient for Diatoms, in Three Mediteranean Coastal Basin Subjected to Different Pollution Sources. International Journal of Ocean and Oceanography, 1(2), 289-298

Setiyono, H. 1996. Kamus Oseanografi. Gadjah Mada University Press. Yogyakarta.

Singh, S., Ebeling, J., Wheaton, F. 1999. Water Quality Trials in Four Recirculating Aquaculture System Configurations. Aquacultural Eng. 20, 75-84.

Skjolstrup, J., Nielsen, P.H., Frier, J.O and McLean, E. 1998. Performance Characteristics of Fluidised Bed Biofilters in a Novel Laboratory-Scale Recirculation System for RainbowTtrout: Nitrification Rates, Oxygen Consumption and Sludge
Collection. Aquacultural Eng. 18, 265-276. Spencer, R.G.M., Butler, K.D and Aiken, G.R. 2012. Dissolved Organic Carbon and Chromophoric Dissolved Organic Matter Properties of Rivers in the USA. Journal of Geophysical Research Vol. 117, G03001, 114

Steward, H.R. 2006. Introduction to Physical Oceanography.Department of Oceanography. A and M University. Texas.

Stickney, R.R. 1979. Principles of Warm Water Aquaculture. John Wiley \& Sons Inc., New York, p. 375.

Sutomo, H, dan Mu'minah, S. 2004. Budidaya Udang Galah. Departemen Kelautan dan Perikanan. Balai Besar Pengembangan Budidaya Air Tawar (BBPBAT), Sukabumi.

Swingle, H. 1969. Standardization of Chemical Analyses for Water and Pond Muds. FAO Fish.

Tarigan. Z, Edward dan Rozak. A. 2003. Kandungan Logam Berat $\mathrm{Pb}, \mathrm{Cd}, \mathrm{Cu}, \mathrm{Zn}$ dan Ni dalam Air Laut dan Sedimen di Muara Sungai Membramo, Papua dalam Kaitannya dengan Kepentingan Budidaya Perikanan. Kelompok Penelitian Pencemaran Laut Balai Dinamika Laut, Pusat Penelitian Oseanografi - LIPI, Jakarta., 7(3), 119-127.

Timmons, M.B., Ebeling, J.M., Wheaton, F.W., Summerfelt, S.T and Vinci, B.J. 2001. Recirculating Aquaculture Systems. Cayuga Aqua Ventures, Ithaca, NY, USA.

Warren-Hansen, I. 1982. Methods of Treatment of Waste Water from Trout Farming. In: Alabaster, J.S (Eds.), EIFAC Technical Paper No.41. Report of the EIFAC Workshop on Fish-Farm Effluents, Silkeborg, Denmark, 26-28 May, 1981. FAO, Rome, 113-121.

Wickens, J.F. 1980. Water Quality Requirements for Intensive Aquaculture: A Review. In: Proceedings of the Symposium on New Developments in the Utilization of Heated Effluents and Recirculation Systems on Intensive Aquaculture, 11th session, pp. 2830.

Wong, K.B. and Piedrahita, R.H. 2000. Settling Velocity Characterization of Aquacultural Solids. Aquacultural. Eng. 21, 233-246. 
Buletin Oseanografi Marina Januari 2014 Vol. 3 No 1 : 9 - 19

Yusuf, Muh. 1994. Dampak Pencemaran Sungai Babon Semarang. Lembaga Terhadap Kualitas Lingkungan Perairan dan Struktur Komunitas Hewan Makrobenthos di Pulau Tirangcawang Semarang. Tesis S2, Program Pascasarjana IPB Bogor.

Yusuf, Muh. 2005. Kajian Dampak Pencemaran Terhadap Kualitas Perairan dan Struktur Komunitas Makrozoobenthos Di Muara

Penelitian, Universitas Diponegoro. Laporan Penelitian Dosen Muda.

Zhao J., Wu Y., Kang Q and Zhang J. 2007. Spatial Variations of Carbon, Nitrogen, Phosphorous and Sulfur in the Salt Marsh Sediments of the Yangtze Estuary in China. Estuarine, Coastal and Shelf Science, 71, 47-59 